\title{
Penerapan Model Seemingly Unrealated Regression (SUR) Spasial pada Tingkat Kasus Kriminalitas di Provinsi Sulawesi Selatan
}

\author{
Adiatma \\ Universitas Islam Negeri Alauddin Makassar, adiatma.rasyid@uin-alauddin.ac.id
}

Irwan

Universitas Islam Negeri Alauddin Makassar, irwan.msi@ uin-alauddin.ac.id

Adnan Sauddin

Universitas Islam Negeri Alauddin Makassar, adnan.sauddin@uin-alauddin.ac.id

\begin{abstract}
This research conducted discusses the crime rate in South Sulawesi Province. There are several main factors that can lead to crime, especially in South Sulawesi Province. This research was conducted to see the Spatial Seemingly Unrealated Regression SUR) model at the crime rate in South Sulawesi Province, but there are assumptions that do not meet the SUR Spatial Analysis, so the model obtained is limited to the Spatial Autoregressive (SAR) and Spatial Eror Model (SEM). The SAR model obtained shows that the population, the number of poor people, and the GDP per capita have a positive and significant effect on the risk of the population being affected by crime. The SEM model obtained shows a positive and significant effect between the population, the number of unemployed has a negative and significant effect on the risk of the population being exposed to crime.
\end{abstract}

\begin{abstract}
ABSTRAK, Penelitian yang dilaksanakan ini membahas tentang tingkat kasus kriminalitas di Provinsi Sulawesi Selatan. Terdapat beberapa faktor utama yang dapat menimbulkan tindak kriminalitas khususnya di Provinsi Sulawesi Selatan. Penelitian ini dilaksanakan untuk mengetahui model Seemingly Unrealated Regression (SUR) Spasial pada tingkat kasus kriminalitas di Provinsi Sulawesi, namun terdapat beberapa asumsi yang tidak memenuhi untuk analisis SUR Spasial maka model yang diperoleh hanya terbatas pada model Spatial Autoregresive (SAR) dan Spatial Error Model (SEM). Model SAR yang diperoleh menunjukkan kepadatan penduduk, jumlah penduduk miskin, dan PDRB Perkapita berpengaruh positif dan signifikan terhadap resiko penduduk terkena kriminalitas. Model SEM yang diperoleh menunjukkan pengaruh positif dan signifikan antara kepadatan penduduk, jumlah penduduk miskin, PDRB perkapita terhadap resiko penduduk terkena kriminalitas, dan jumlah pengangguran berpengaruh negatif dan signifikan terhadap resiko penduduk terkena kriminalitas.
\end{abstract}

Keywords: Crime, SUR, SAR, and SEM

Kata Kunci: Kriminalitas, SUR, SAR, dan SEM

\section{PENDAHULUAN}

Kriminalitas dikenal sebagai suatu tindakan kejahatan yang melanggar akidah hukum.[1] Berdasarkan penelitian sebelumnya oleh Alia Lestari dan Muh.Hajarul A.A. (2016) menunjukkan bahwa pada wilayah naungan hukum Polres Kota Palopo untuk tindak kejahatan tertinggi yang terjadi yaitu pencurian kendaraan bermotor sedangkan untuk tindak kejahatan terendah yaitu penganiayaan.[2] Menurut Lederman et al (2001) menyatakan bahwa semakin timpang perekonomian suatu kota atau negara maka akan semakin tinggi tingkat kriminalitas, sehingga ketimpangan ekonomi dapat menjadi faktor utama penyebab tindakan kriminalitas. Untuk mengetahui faktorfaktor yang mempengaruhi tindak kriminalitas maka diperlukan sebuah analisis khusus. Salah satunya yaitu analisis SUR Spaisal. Berdasarkan penelitian sebelumnya oleh Liya Misdiati (2014) menunjukkan bahwa untuk membentuk model dari faktor perekonomian kemiskinan, pengangguran, dan PDRB di Jawa Timur, model seemingly unrealated regression spatial menggunakan bobot customize memperoleh nilai RMSE lebih rendah dengan nilai $R^{2}$ lebih tinggi jika dibandingkan dengan bobot Queen Contiguity.[3] SUR Spasial terdiri dari beberapa struktur, diantaranya SUR Spatial Autoregresive (SUR-SAR) dan SUR Spatial Error Model (SUR-SEM). Berdasarkan penelitian sebelumnya oleh Irma Yunita dan Timbang Sirait (2017) menggunakan analisis SAR menunjukkan bahwa jumlah angkatan kerja, pengeluaran perkapita, pertumbuhan ekonomi, dan PDRB berpengaruh signifikan terhadap upah minimum 
Kabupaten/Kota di Pulau Kalimantan.[4] Selain itu, penelitian sebelumnya oleh Diana Wahyu dkk (2014) menggunakan pemodelan SEM menunjukkan bahwa terjadi pola pengelompokkan wilayah di Provinsi Jawa Tengah dengan tingkat IPM yang tersebar dimana nilai lambda dan seluruh variabel berpengaruh signifikan terhadap IPM.[5] Terdapat pula penelitian sebelumnya oleh Musfika Rati (2013) menggunakan analisis Regresi Spasial menunjukkan bahwa jumlah penduduk prasejahtera, jumlah Sekolah Dasar, rasio antara anak yang bersekolah dengan Anak Tidak Bersekolah (ATB) kurang dari 15 tahun berpengaruh terhadap jumlah Anak Tidak Bersekolah (ATB) kurang dari 15 tahun.[6]

\section{TINJAUAN PUSTAKA}

\section{Model Seemingly Unrealated Regression (SUR)}

Menurut Zellner (1962), model Seemingly Unrealated Regression (SUR) dikenal sebagai model kompleks dari model regresi linear, dimana model $S U R$ terdiri dari beberapa model regresi. Adapun model umum dari model SUR menurut Kmenta (1971) yaitu sebagai berikut: $y_{1 i}=\beta_{11} X_{1 i, 1}+\beta_{12} X_{1 i, 2}+\cdots+\beta_{1 K_{1}} X_{1 i, K_{1}}+$

$$
\begin{aligned}
& \varepsilon_{1 i} \\
y_{2 i}= & \beta_{21} X_{2 i, 1}+\beta_{22} X_{2 i, 2}+\cdots+\beta_{2 K_{2}} X_{2 i, K_{2}}+ \\
& \varepsilon_{2 i} \\
& \vdots \\
y_{M t}= & \beta_{M 1} X_{M i, 1}+\beta_{M 2} X_{M i, 2}+\cdots+ \\
& \beta_{M K_{M}} X_{M i, K_{M}}+\varepsilon_{M i}
\end{aligned}
$$

dimana, $i=1,2, \ldots, N$

Dengan menggunakan notasi matriks, maka persamaan (2.1) menjadi

$$
\begin{aligned}
& y_{1}=X_{1} \beta_{1}+\varepsilon_{1} \\
& y_{2}=X_{2} \beta_{2}+\varepsilon_{2} \\
& \vdots \\
& y_{M}=X_{M} \beta_{M}+\varepsilon_{M}
\end{aligned}
$$

atau persamaan (2.1) dapat ditulis

$$
\boldsymbol{y}_{m}=\boldsymbol{X}_{m} \boldsymbol{\beta}_{m}+\boldsymbol{\varepsilon}_{m} \quad(m=1,2, \ldots, M) .
$$

dimana

$$
\boldsymbol{y}_{m}=\operatorname{vektor}(N \times 1)
$$

$$
\begin{aligned}
& \boldsymbol{X}_{m}=\text { matrik }\left(N \times K_{m}\right) \\
& \boldsymbol{\beta}_{m}=\operatorname{vektor}\left(K_{m} \times 1\right) \\
& \boldsymbol{\varepsilon}_{m}=\operatorname{vektor}(N \times 1)
\end{aligned}
$$

Pada sistem pemodelan SUR, Kmenta (1971) mengasumsikan bahwa $\boldsymbol{\varepsilon}_{m}$ adalah berdistribusi normal dengan mean

$$
E\left(\boldsymbol{\varepsilon}_{m i}\right)=0 \quad(i=1,2, \ldots, N)
$$

dan matrik varians-kovarians diperoleh dari

$$
E\left(\varepsilon_{m} \varepsilon_{m}^{T}\right)=\sigma_{m m} I_{N}
$$

dimana $I_{N}=$ matrik identitas $(N \times N)$.

Perlu diketahui bahwa setiap persamaan diharapkan memenuhi asumsi dari model regresi linear klasik. Artinya tidak bisa mengesampingkan kemungkinan distribusi regresi pada setiap persamaan yang berbeda saling berkorelasi. Dalam hal ini diperoleh

$E\left(\varepsilon_{m} \varepsilon_{p}^{T}\right)=\sigma_{m p} I_{N}(m, p=1,2, \ldots, M)$

Dalam melakukan perhitungan hubungan error antar persamaan, maka persamaan (2.1) disederhanakan menjadi

$$
\left[\begin{array}{c}
y_{1} \\
y_{2} \\
\vdots \\
y_{M}
\end{array}\right]=\left[\begin{array}{cccc}
X_{1} & 0 & \cdots & 0 \\
0 & X_{2} & \cdots & 0 \\
\vdots & \vdots & \ddots & \vdots \\
0 & 0 & \cdots & X_{M}
\end{array}\right]\left[\begin{array}{c}
\beta_{1} \\
\beta_{2} \\
\vdots \\
\beta_{M}
\end{array}\right]+\left[\begin{array}{c}
\varepsilon_{1} \\
\varepsilon_{2} \\
\vdots \\
\varepsilon_{M}
\end{array}\right]
$$

Selain itu, persamaan (2.1) juga dapat ditulis

$$
\boldsymbol{y}=\boldsymbol{X} \boldsymbol{\beta}+\varepsilon
$$

dimana

$$
\begin{aligned}
& \boldsymbol{y}=\operatorname{vektor}(M N \times 1) \\
& \boldsymbol{X}=\text { matrik }\left(M N \times \sum_{m=1}^{M} K_{m}\right) \\
& \boldsymbol{\beta}=\text { matrik }\left(\sum_{m=1}^{M} K_{m} \times 1\right) \\
& \boldsymbol{\varepsilon}=\operatorname{vektor}(M N \times 1)
\end{aligned}
$$

Dengan mengasumsikan persamaan (2.2) melalui persamaan (2.4), maka struktur matrik varians-kovarians $\boldsymbol{\varepsilon}$ adalah

$$
\Omega=E\left(\varepsilon \varepsilon^{T}\right)
$$

$$
\begin{aligned}
\Omega & =\left[\begin{array}{cccc}
E\left(\varepsilon_{1} \varepsilon_{1}^{T}\right) & E\left(\varepsilon_{1} \varepsilon_{2}^{T}\right) & \ldots & E\left(\varepsilon_{1} \varepsilon_{M}^{T}\right) \\
E\left(\varepsilon_{2} \varepsilon_{1}^{T}\right) & E\left(\varepsilon_{2} \varepsilon_{2}^{T}\right) & \ldots & E\left(\varepsilon_{2} \varepsilon_{M}^{T}\right) \\
\vdots & \vdots & & \vdots \\
E\left(\varepsilon_{M} \varepsilon_{1}^{T}\right) & E\left(\varepsilon_{M} \varepsilon_{2}^{T}\right) & E\left(\varepsilon_{M} \varepsilon_{M}^{T}\right)
\end{array}\right] \\
\Omega & =\left[\begin{array}{cccc}
\sigma_{11} I & \sigma_{12} I & \ldots & \sigma_{1 M} I \\
\sigma_{21} I & \sigma_{22} I & \ldots & \sigma_{2 M} I \\
\vdots & \vdots & & \vdots \\
\sigma_{M 1} I & \sigma_{M 2} I & & \sigma_{M M} I
\end{array}\right]
\end{aligned}
$$


$\Omega=\left[\begin{array}{cccc}\sigma_{11} & \sigma_{12} & \cdots & \sigma_{1 M} \\ \sigma_{21} & \sigma_{22} & \cdots & \sigma_{2 M} \\ \vdots & \vdots & & \vdots \\ \sigma_{M 1} & \sigma_{M 2} & & \sigma_{M M}\end{array}\right] \otimes \boldsymbol{I}_{N}$

$\Omega=\boldsymbol{\Sigma} \otimes \boldsymbol{I}_{N}$

dengan $\boldsymbol{I}_{N}$ merupakan matrik yang berukuran $(N \times N)$.

\section{Model Regresi Spasial}

Regresi spasial dikenal sebagai metode analisis untuk mengetahui pengaruh antara variabel prediktor dan variabel respon dengan melihat kaitan antar wilayah. Anselin (1988) mengembangkan model umum dari model regresi spasial yaitu sebagai berikut:

$$
\begin{gathered}
\mathbf{y}=\rho \mathbf{W}_{\mathbf{1}} \mathbf{y}+\mathbf{X} \boldsymbol{\beta}+\mathbf{u} \\
\operatorname{dimana}, \mathbf{u}=\lambda \mathbf{W}_{\mathbf{2}}+\boldsymbol{\varepsilon} \\
\boldsymbol{y}=\left(\mathbf{I}_{N}-\rho \mathbf{W}_{\mathbf{1}}\right)^{-\mathbf{1}} \mathbf{X} \boldsymbol{\beta}+\left(\mathbf{I}_{N}-\right. \\
\left.\rho \mathbf{W}_{\mathbf{1}}\right)^{-\mathbf{1}}\left(\mathbf{I}_{N}-\lambda \mathbf{W}_{\mathbf{2}}\right)^{-\mathbf{1}} \boldsymbol{\varepsilon} \\
\boldsymbol{\varepsilon} \sim N\left(\mathbf{0}, \sigma^{2} \mathbf{I}_{N}\right)
\end{gathered}
$$

dimana,

$\boldsymbol{y}: \operatorname{vektor}(N \times 1)$

$\boldsymbol{X}$ : matriks $(N \times(M+1))$

$\boldsymbol{\beta}$ : vektor $((M+1) \times N)$

$\rho$ : koefisien spasial lag dari variabel dependen.

$\lambda$ : koefisien spasial autoregressive dari error regresi.

$\boldsymbol{u}$ : vektor spasial autokorelasi dari error regresi $(N \times 1)$

$\boldsymbol{\varepsilon}$ : vektor error regresi $(N \times 1)$ yang bersifat identik independen dan berdistribusi normal.

$\boldsymbol{W}_{\mathbf{1}}$ dan $\boldsymbol{W}_{\mathbf{2}}$ : matriks pembobot/penimbang spasial $(N \times N)$ yang elemen diagonalnya bernilai nol.

\section{Dependensi Spasial}

Menurut Anselin (1988), dependensi spasial dikenal sebagai kejadian pada satu titik dalam sebuah ruang dan kejadian lain di tempat lainnya pula yang memiliki hubungn fungsional. Adapun untuk menguji nilai dependensi spasial dapat dilakukan dengan melihat indeks Moran's I, dimana:

- $H_{0}: I_{j}=0$, maka tidak terjadi dependensi spasial

- $H_{1}: I_{j} \neq 0$, maka terjadi dependensi spasial
Kemudian statistik uji yang digunakan dalam pengujian signifikansi pada indeks Moran's I menurut Cliff dan Ord (1981) yang dirumuskan pada persamaan (2.7).

$$
\text { - } Z=\frac{\left[I_{j}-E\left(I_{j}\right)\right]}{\operatorname{var}\left(I_{j}\right)^{\frac{1}{2}}}
$$

dengan

$H_{0}$ ditolak jika $Z>Z \alpha / 2$. Nilai indeks Morans's I besarnya antara -1 sampai 1 . Jika $I_{j}>E\left(I_{j}\right)$ maka data memiliki autokorelasi positif dan jika $I_{j}<E\left(I_{j}\right)$ maka data memiliki autokorelasi negatif.

\section{Heterogenitas Spasial}

Menurut Anselin (1988), heterogenitas spasial dikenal sebagai strategi khusus untuk kejadian ketidakseragaman efek spasial di masing-masing wilayah. Adapun untuk menguji nilai heterosgenitas spasial dapat dilakukan dengan uji Breush-Pagan, dimana:

- $H_{0}: \sigma_{1}^{2}=\sigma_{2}^{2}=\cdots=\sigma_{N}^{2}=\sigma^{2}, \quad$ maka terjadi homoskedastisitas

- $H_{1}$ : paling tidak ada satu $\sigma_{i}^{2} \neq \sigma_{j}^{2}$, maka terjadi heteroskedastisitas

Kemudian statistik uji yang digunakan pada uji Breush-Pagan menurut Anselin

(1988) dirumuskan pada persamaan (2.8).

$$
B P=(1 / 2) \boldsymbol{f}^{T} \boldsymbol{Z}\left(\boldsymbol{Z}^{T} \boldsymbol{Z}\right)^{-1} \boldsymbol{Z}^{T} \boldsymbol{f}
$$

dengan

$\boldsymbol{f}=$ vektor $(N \times 1)$ dengan elemenya adalah $\frac{\varepsilon_{i}^{2}}{\sigma^{2}}-1$

$\varepsilon_{i}=$ vektor error observasi ke- $i$ hasil regresi OLS

$\sigma^{2}=$ varians berdasarkan error OLS

$\boldsymbol{Z}=$ matrik $(N \times(M+1))$ dengan elemennya merupakan variabel prediktor yang telah dinormal standarkan.

Nilai statistik uji $B P$ asimtotik dengan distribusi $\chi_{\left(p_{j}+1\right)}^{2}$, sehingga $H_{0}$ ditolak jika $B P>$ $\chi_{\left(p_{j}+1, \alpha\right)}^{2}$ atau P-value kurang dari $\alpha$. 


\section{Pembobot Spasial}

Adapun untuk memperoleh matriks pembobot atau penimbang spasial $(W)$ dapat dilakukan dengan melihat informasi jarak antar satu wilayah dengan wilayah lainnya. Ada beberapa metode untuk mendefinisikan hubungan persinggungan (contiguity) antar lokasi tersebut. Menurut LeSage (1999) bahwa metode tersebut antara lain:

a) Linear contiguity (persinggungan tepi); mendefinisikan $\mathrm{w}_{i j}=1$ untuk lokasi yang berada di tepi (edge) kiri maupun kanan lokasi yang menjadi perhatian, $\mathrm{w}_{i j}=0$ untuk lokasi lainnya.

b) Rook contiguity (persinggungan sisi); mendefinisikan $\mathrm{w}_{i j}=1$ untuk lokasi yang bersisian (common side) dengan lokasi yang menjadi perhatian, $\mathrm{w}_{i j}=0$ untuk lokasi lainnya.

c) Bhisop contiguity (persinggungan sudut); mendefinisikan $w_{i j}=1$ untuk lokasi yang titik sudutnya (common vertex) bertemu dengan sudut lokasi yang menjadi perhatian, $\mathrm{w}_{i j}=0$ untuk lokasi lainnya.

d) Double linear contiguity (persinggungan dua tepi); mendefinisikan $\mathrm{w}_{i j}=1$ untuk dua entity yang berada di sisi (edge) kiri dan kanan lokasi yang menjadi perhatian, $\mathrm{w}_{i j}=0$ untuk lokasi lainnya.

e) Double rook contiguity (persinggungan dua sisi); mendefinisikan $\mathrm{w}_{\mathrm{i} j}=1$ untuk dua entity di kiri, kanan, utara dan selatan lokasi yang menjadi perhatian, $\mathrm{w}_{i j}=0$ untuk lokasi lainnya.

f) Queen contiguity (persinggungan sisi-sudut); mendefinisikan $\mathrm{w}_{i j}=1$ untuk entity yang bersisian (common side) atau titik sudutnya (common vertex) bertemu dengan lokasi yang menjadi perhatian, $\mathrm{w}_{i j}=0$ untuk lokasi lainnya.

\section{Model SUR Spasial}

Model umum SUR spasial dikenal sebagai model yang terdiri dari beberapa struktur diantaranya yaitu SUR-Spatial Autoregresive (SUR-SAR) dengan struktur autoregresif yang terdapat pada persamaan utama dan error. Terdapat pula model SUR-Spatial Lag Model
(SUR-SLM) dengan struktur autoregresif yang hanya terdapat pada persamaan utama dan model SUR-Spatial Error Model (SUR-SEM) dengan struktur autoregresif yang hanya terdapat pada nilai error.

\section{Tingkat Kriminalitas}

Menurut Romli (2013), tindakan kriminalitas dapat terjadi oleh beberapa faktor diantaranya yaitu tingginya tingkat pengangguran, kurangnya lapangan pekerjaan, maupun jumlah penduduk miskin. Namun diluar dari faktor-faktor tersebut masih terdapat faktor lainnya yang mendorong seseorang untuk mencukupi ekonominya dengan cara yang kurang tepat.

\section{METODOLOGI PENELITIAN}

Data yang digunakan merupakan data sukender yang bersumber dari Instansi Kepolisian Daerah Sulawesi Selatan dan BPS Provinsi Sulawesi Selatan dengan unit observasi berjumlah 23 Kabupaten/Kota yang berada di Provinsi Sulawesi Selatan. Adapun variabel yang digunakan pada penelitian ini merupakan beberapa tindakan kriminalitas dan faktor-faktor yang mendorong tindakan kriminalitas. Adapun variabel-variabel tersebut yaitu sebagai berikut:

1. $Y_{1}$ : tingkat kasus kekerasan

2. $Y_{2}$ : tingkat kasus pencurian

3. $Y_{3}$ : tingkat kasus penipuan

4. $X_{1}$ : kepadatan penduduk

5. $X_{2}:$ persentase penduduk miskin

6. $X_{3}$ : PDRB perkapita

7. $X_{4}$ : penyelesaian tagihan

8. $X_{5}:$ IPM

\section{Prosedur Penelitian}

Adapun prosedur penelitian yang dilaksanakan yaitu sebagai berikut:

1. Membuat statistik deskriptif dari masingmasing variabel.

2. Mengidentifikasi pola hubungan antara variabel dependen dan independen.

3. Melakukan standardisasi data.

4. Melakukan pemodelan regresi linear berganda. 
5. Menentukan pembobot spasial menggunakan metode Queen Contiguity.

6. Melakukan pegujian aspek spasial diantaranya dependensi spasial dan heterogenitas spasial.

7. Melakukan uji kecocokan model spasial menggunakan LM-test dan Robust LM.

8. Membentuk model menggunakan pendekatan SUR spasial.

9. Melakukan interpretasi dari model SUR spasial yang terbentuk.

\section{HASIL DAN PEMBAHASAN}

\section{Studi Kasus}

\section{Peta Administratif Provinsi Sulawesi Selatan}

Adapun peta administrative Provinsi Sulawesi Selatan yaitu sebagai berikut.

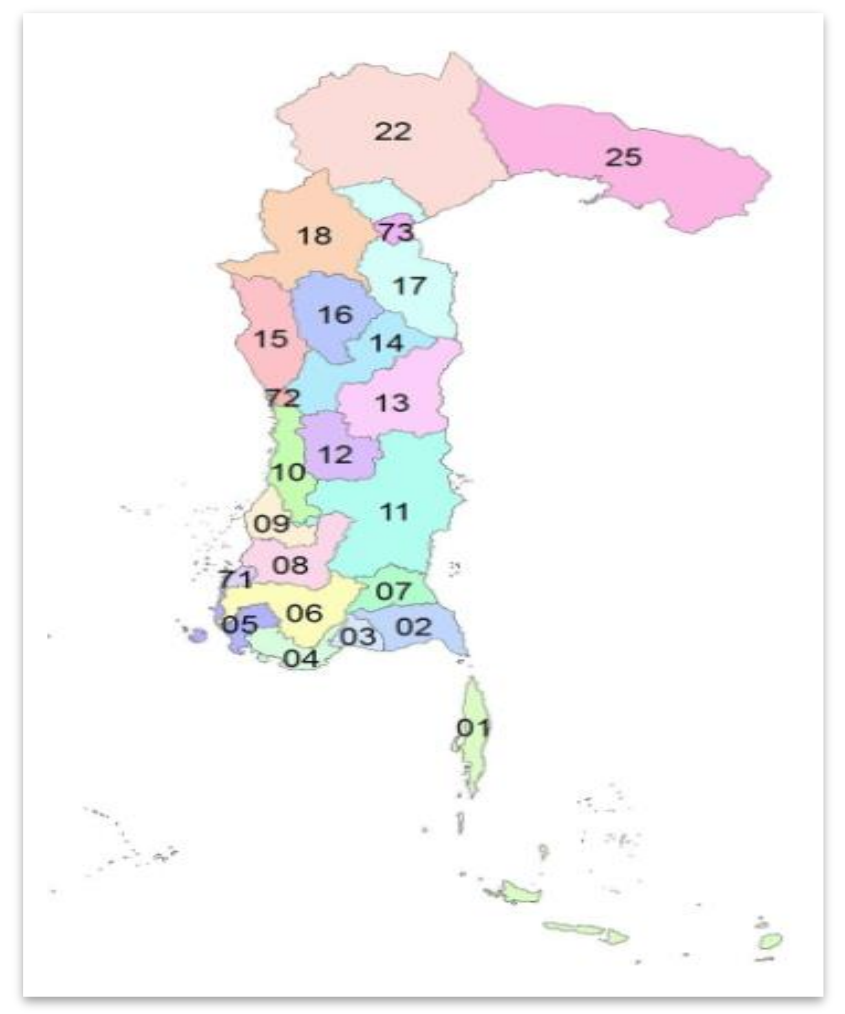

Gambar 4.1 Peta Administratif Provinsi Sulawesi Selatan

Keterangan dari Gambar 4.1 dengan kode (01) Kepulauan Selayar, (02) Bulukumba, (03) Bantaeng, (04) Jeneponto, (05) Takalar, (06) Gowa, (07) Sinjai, (08) Maros, (09) Pangkep, (10) Barru, (11) Bone, (12) Soppeng, (13) Wajo, (14) Sidrap, (15) Pinrang, (16) Enrekang, (17) Luwu, (18) Tana Toraja, (22) Luwu Utara, (25) Luwu Timur, (71) Makassar, (72) Pare-pare, dan (73) Palopo.

\section{Ekplorasi Data}

Adapun ekplorasi data dilakukan dengan pemetaan tematik resiko penduduk terkena tindakan kriminalitas di Provinsi Sulawesi Selatan yaitu sebagai berikut.

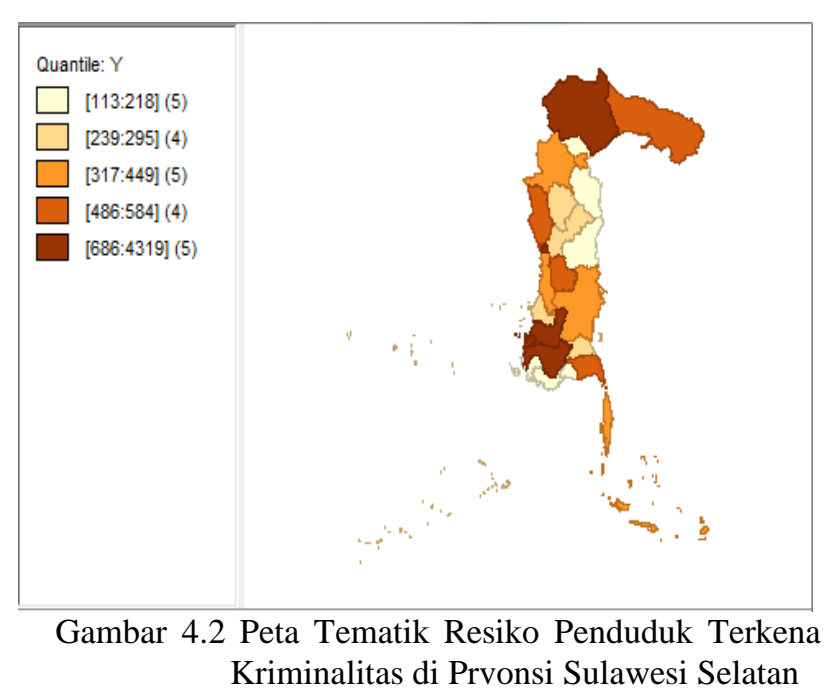

Berdasarkan ekplorasi data dengan peta tematik pada Gambar 4.2 maka dapat dilihat tingkat resiko penduduk terkena kriminalitas dikategorikan menjadi lima kategori yaitu kategori sangat rendah dengan (113-420 penduduk), kategori rendah dengan (239-295 penduduk), kategori sedang dengan (317-449 penduduk), kategori tinggi dengan (486-594 penduduk), dan kategori sangat tinggi dengan (686-4319 penduduk).

\section{Pemodelan Regresi Linear Berganda}

Pemodelan dengan regresi linier berganda dilakukan untuk mengetahui parameter yang signifikan mempengaruhi tingkat kriminalitas di Kabupaten/Kota di Sulawesi Selatan dengan menggunakan persamaan tunggal. Selain itu, pemodelan dengan regresi linier berganda juga dilakukan untuk mendapatkan error model sehingga dapat dilakukan pengujian aspek spasial. Berdasarkan hasil estimasi parameter model regresi linier berganda dapat diketahui korelasi antar error model sebagai berikut. 
Tabel 4.1 Korelasi Antar Error Model

\begin{tabular}{|c|c|c|c|c|c|c|}
\hline \multirow{2}{*}{ Error } & \multicolumn{2}{|c|}{$Y_{1}$} & \multicolumn{2}{|c|}{$Y_{2}$} & \multicolumn{2}{|r|}{$Y_{3} \quad$ dependen dengan nilai $p-$ value $<\alpha(0,1)$} \\
\hline & Nilai & Sig. & Nilai & Sig. & ilai & $\begin{array}{l}\text { Sig. Estimasi parameter selanjutnya dilakukan } \\
\text { untuk memneroleh model reoresi terbaik vaitu }\end{array}$ \\
\hline$Y_{1}$ & & & 0,341 & 0,347 & 0,514 & 0,21 lengan membentuk kembali variabel kepada \\
\hline$Y_{2}$ & 0,341 & 0,347 & & & 0,607 & 0,71penduduk $\left(X_{1}\right)$. Estimasi parameter $\mathrm{mc}$ \\
\hline$Y_{3}$ & 0,514 & 0,210 & 0,607 & 0,716 & & \\
\hline
\end{tabular}

Berdasarkan Tabel 4.1 di atas dapat dikatakan bahwa tidak terdapat korelasi antar error model pada tingkat kasus kekerasan $\left(Y_{1}\right)$, tingkat kasus pencuian $\left(Y_{2}\right)$, dan tingkat kasus penipuan $\left(Y_{3}\right)$. Hal tersebut dapat dilihat dari signifikansi pada $\alpha=0,01$. Jadi dapat disimpulkan bahwa model yang akan dibentuk tidak bisa menggunakan model Seemingly Unrelated Regression karena asumsi model tidak terpenuhi. Oleh sebab itu, model yang akan digunakan terbatas pada model regresi spasial. Namun perlu diketahui bahwa variabel yang digunakan digabungkan menjadi satu variabel respon yaitu tingkat kasus kriminalitas.

Adapun untuk mengetahui parameter yang signifikan berpengaruh terhadap resiko penduduk terkena kriminalitas di Provinsi Sulawesi Selatan dapat dilakukan dengan estimasi parameter pada model regresi berganda. Estimasi parameter model regresi berganda yaitu sebagai berikut.

Tabel 4.2 Estimasi Parameter Model Regresi Berganda

\begin{tabular}{|c|c|c|c|c|}
\hline Variabel & Coefisien & $\begin{array}{c}\text { Std. } \\
\text { Error }\end{array}$ & t-Stat. & -value \\
\hline Konta & 2422,086 & 2658,99 & 0,91009 & 750 \\
\hline$X_{1}$ & 04720 & 01804 & 2,6218 & $0,0178^{*}$ \\
\hline$X_{2}$ & 11910 & 6,8936 & & 0,1190 \\
\hline$X_{3}$ & 0,1538 & 0,1073 & 1,4336 & 0,1698 \\
\hline$X_{4}$ & 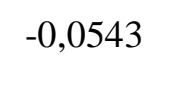 & 0,0449 & $-1,2087$ & 0,2432 \\
\hline$X_{5}$ & 32,1343 & 35,3898 & 0,9080 & 0,3765 \\
\hline
\end{tabular}

R-squared $=85,9 \%$

*) Signifikan pada $\alpha=10 \%$

Berdasarkan Tabel 4.2 dapat dilihat bahwa hanya variabel kepadatan penduduk $\left(X_{1}\right)$ yang
Tabel 4.3 Estimasi Parameter Model Regresi Klasik Terbaik

\begin{tabular}{ccccc}
\hline Variabel & Koefisien & $\begin{array}{c}\text { Std. } \\
\text { Error }\end{array}$ & t-Stat. & p-value \\
\hline Konstanta & 315,772 & 86,4160 & 3,6540 & $0,0014^{*}$ \\
$X_{1}$ & 0,5034 & 0,0516 & 9,7426 & $0,0000^{*}$ \\
\hline
\end{tabular}

R-squared $=81,8 \%$

*) Signifikan pada $\alpha=10 \%$

Berdasarkan estimasi parameter model regresi klasik maka persamaan regresi yang diperoleh yaitu sebagai berikut.

$$
\widehat{y}_{l}=315,772+0,5034 X_{1 i} \text {. }
$$

\section{Matriks Contiguity}

Matriks pembobot dapat dilakukan dengan standarisasi matriks contiguity. Susunan matriks akan membentuk ukuran 23 x 23 yang diperoleh dari jumlah observasi Kabupaten/Kota di Provinsi Sulawesi Selatan.

\section{Dependensi Spasial}

\section{Moran's I}

Adapun hasil dari pengujian efek spasial menggunakan uji Moran's I yaitu sebagai berikut:

Tabel 4.4 Hasil Uji Moran's I

\begin{tabular}{ccc}
\hline Variabel & Moran's I & $\mathbf{Z}(\mathbf{I})$ \\
\hline$Y$ & 0,11889 & 0,41851 \\
$X_{1}$ & $-0,01774$ & 0,28188 \\
$X_{2}$ & 0,08274 & 0,38236 \\
$X_{3}$ & $-0,06733$ & 0,23229 \\
$X_{4}$ & $-0,03210$ & 0,26752 \\
$X_{5}$ & 0,11609 & 0,41571 \\
\hline$Z_{0,05}=1,645$ & & \\
$I_{0}=-0,0454$ & &
\end{tabular}

Berdasarkan Tabel 4.4 dapat dilihat bahwa seluruh variabel dependen maupun independen memperoleh nilai $Z(I)<Z_{\alpha / 2}=1,645$ maka 
dapat diasumsikan tidak terjadi depensi spasial antar daerah atau tolak $H_{0}$. Selain itu, nilai $I_{0}$ yang diperoleh menunjukkan bahwa variabel dependen maupun independen kecuali variabel PDRB perkapita $\left(X_{3}\right)$ cenderung terindikasi terjadi dependensi spasial yang positif maka dapat diasumsikan wilayah yang berdekatan memiliki nilai yang mirip dan cenderung berkelompok.

\section{Lagrange Multiplier (LM)}

Adapun hasil dari pengujian efek spasial menggunakan uji Lagrange Multiplier (LM) yaitu sebagai berikut.

Tabel 4.5 Hasil Diagnostik Dependensi Spasial

\begin{tabular}{lcc}
\multicolumn{1}{c}{$\begin{array}{c}\text { Uji Dependensi } \\
\text { Spasial }\end{array}$} & Nilai & p-value \\
\hline $\begin{array}{l}\text { Moran's I } \\
\begin{array}{l}\text { Lagrange } \\
\text { Multiplier (lag) }\end{array}\end{array}$ & $-0,3236764$ & 0,7461832 \\
$\begin{array}{l}\text { Lagrange } \\
\text { Multiplier (error) }\end{array}$ & 0,5296950 & 0,3349422 \\
$\begin{array}{l}\text { Lagrange } \\
\begin{array}{l}\text { Multiplier } \\
\text { (SARMA) }\end{array}\end{array}$ & 3,1437015 & 0,2076605 \\
\hline
\end{tabular}

Berdasarkan Tabel 4.5 dapat dilihat bahwa tidak satupun nilai $p$-value baik LM lag maupun error yang signifikan, artinya tidak ada dependensi spasial baik lag maupun error.

\section{Model Regresi Spasial}

Analisis selanjutnya adalah memodelkan faktor-faktor yang mempengaruhi resiko penduduk terkena kriminalitas dengan menggunakan SAR dan SEM. Hasil analisis tersebut diperoleh menggunakan OpenGeoda. Adapun hasil dari persamaan SAR yaitu sebagai berikut.

$$
\begin{aligned}
\hat{y}_{i}= & -3065,24+0,1378 \sum_{j=1, i \neq j}^{23} W_{i j} y_{j}+ \\
& 0,4529 X_{1}+11,0596 X_{2}+0,1622 X_{3}- \\
& 0,0563 X_{4}+39,95609 X_{5}
\end{aligned}
$$

Adapun hasil dari persamaan SEM yaitu sebagai berikut.

$$
\begin{array}{r}
\hat{y}_{i}=-1527,094+0,5631 X_{1}+14,6860 X_{2}+ \\
0,1745 X_{3}-0,0612 X_{4}+17,6411 X_{5}+u_{i}
\end{array}
$$

dengan $u_{i}=-0,9294 \sum_{j=1, i \neq j}^{23} W_{i j} y_{j}$

\section{Perbandingan Model Klasik dan Model Regresi Spasial}

Adapun hasil dari perbandingan model klasik dan model regresi spasial yaitu sebagai berikut:

Tabel 4.6 Ukuran Kebaikan Model Regresi Klasik dan Regresi Spasial

\begin{tabular}{ccc}
\hline Model & $\mathbf{R}^{\mathbf{2}}$ & AIC \\
\hline OLS & $85,9 \%$ & 343,111 \\
SAR & $86,5 \%$ & 344,22 \\
SEM & $90,1 \%$ & 339,824 \\
\hline
\end{tabular}

Berdasarkan Tabel 4.6 terlihat bahwa model yang terbaik diperoleh dari model SEM dengan nilai $\mathrm{R}^{2}$ yang lebih besar dan nilai AIC yang kecil, meskipun demikian nilai lamda pada model SEM bernilai negatif dan signifikan sehingga model SEM tidak layak digunakan. Maka model terbaik pada penelitian ini adalah model SAR dengan nilai $\mathrm{R}^{2}$ sebesar $86,5 \%$ dengan nilai rho yang positif dan tidak signifikan, namun model yang dihasilkan pada model ini tidak mempunyai keterkaitan spasial secara signifikan terjadinya kasus kriminalitas antara suatu Kabupaten/Kota dengan Kabupaten/Kota yang lainnya.

\section{KESIMPULAN}

Data yang dianalisis tidak memenuhi asumsi untuk analisis SUR Spasial. Oleh karena itu, analisis hanya terbatas pada analisis regresi spasial yaitu Spatial Autorgeressive (SAR) dan Spatial Error Model (SEM). Berdasarkan hasil analisis resiko penduduk terkena kriminalitas tidak menunjukkan adanya dependensi spasial baik dalam lag maupun error nya.

\section{DAFTAR PUSTAKA}

[1] Khairul Ihsan, "Factors Cause OfChildren Criminal Action (Case Study Of Prisons Pekan Baru Class II B) ", JOM FISIP Vol. 3 No. 2 - Oktober 2016

[2] Alia Lestari dan Muhammad Hajarul Aswad A, "Pemetaan Tindak Kriminalitas 
Di Kota Palopo Tahun 2015”, Journal of Social-Religi Research Vol. 1 No. 1 April 2016, hal. 29-44

[3] Liya Misdiati, "Pemodelan Faktor Perekonomian di Jawa Timur Menggunakan Seemingly Unrealated Regression”, Tesis SS09-2304 Tahun 2014

[4] Irma Yunita dan Timbang Sirait, "Penerapan SAR Pada Upah Minimum Kabupaten/Kota Di Pulau Kalimantan Tahun 2017”, Politeknik Statistika STIS

[5] Diana Wahyu dkk, "Pemodelan Spatial Error Model (SEM) Untuk Indeks Pembangunan Manusia (IPM) di Provinsi Jawa Tengah", Statistika Vol. 2 No. 2 November 2014

[6] Musfika Rati dkk, “Model Regresi Spasial Untuk Anak Tidak Bersekolah Usia Kurang 15 Tahun di Kota Medan", Saintia Matematika Vol. 1 No. 1 Tahun 2013, pp 87-99

[7] Anselin, L., "Spatial Econometrics: Methods and Models", Kluwer Academic, Dordrecht, Tahun 1988

[8] Cliff, A. dan Ord. J., "Spatial Processes, Models and Applications", Pion, London, Tahun 1981

[9] Romli, "Teori dan Kapita Selekta Kriminologi", Cetakan keempat, PT. Refika Aditama, Bandung, Tahun 2013

[10] Kmenta, J, "Elements of Econometrics", Edisi Kedua, Macmillan Publishing Company, New York, Tahun 1971 